\title{
Enkapsulasi Ekstrak Antosianin dari Bunga Rosela (hibiscus sabdariffa l.) dengan Variasi Penyalut
}

\author{
Raisi A Oktavi ; Bambang Cahyonoa; Meiny Suzerya* \\ ${ }^{a}$ Departemen Kimia, Fakultas Sains dan Matematika, Universitas Diponegoro, Semarang
}

\begin{abstract}
Encapsulation of anthocyanin extract from Rosella petals using extrusion method with coating variation namely Ca-alginate, chitosan-TPP and Ca-alginate/chitosan has been done. This study aimeds to determine the exact coating of the three coating variations for anthocyanin extract encapsulated in terms of encapsulation efficiency values and antioxidant activity, also to determine the stability of product that exhibit the greatest antioxidant activity against temperature $\left(4,25\right.$ dan $\left.40^{\circ} \mathrm{C}\right)$ and storage time $(0,6$ and 16 days). The measurement of total anthocyanin encapsulated as cyaniding-3-glucoside was performed by using the $p H$-differential method. The results showed that the best encapsulation products were obtained in atc-alg/cts encapsulation product that provided an encapsulation efficiency value of $98.28 \%$. The greatest antioxidant activity was obtained in atc-alg/cts products with an IC 50 value of 4079.88 ppm. Stability analysis showed the product can still be stored at $25^{\circ} \mathrm{C}$. The lowest total encapsulated anthocyanins were shown in product with a storage temperature of $40^{\circ} \mathrm{C}$ for 16 days of $9.02 \mathrm{mg} / \mathrm{L}$. Based on these results it can be concluded that the appropriate coating for the anthocyanin extract encapsulation product was Ca-alginate/chitosan coating..
\end{abstract}

Keywords: Encapsulation, Extrusion, Anthocyanin, Alginate, Chitosan

\begin{abstract}
Abstrak
Enkapsulasi ekstrak antosianin dari kelopak bunga Rosela menggunakan metode ekstrusi dengan variasi penyalut yaitu Ca-alginat, kitosan-TPP dan Ca-alginat/kitosan telah dilakukan. Penelitian ini bertujuan untuk menentukan penyalut yang tepat dari ketiga variasi penyalut untuk produk enkapsulasi ekstrak antosianin dalam hal nilai efisiensi enkapsulasi dan aktivitas antioksidan, serta menentukan stabilitas dari produk yang menunjukkan aktivitas antioksidan terbesar terhadap temperatur (4, 25 dan $40{ }^{\circ} \mathrm{C}$ ) dan waktu penyimpanan (hari ke-0, 6 dan 16). Pengukuran total antosianin terenkapsulasi sebagai sianidin-3-glukosida dilakukan menggunakan metode pH-diferensial. Hasil penelitian menunjukan produk enkapsulasi terbaik diperoleh pada produk enkapsulasi atc-alg/cts yang memberikan nilai efisiensi enkapsulasi sebesar 98,28\%. Aktivitas antioksidan terbesar diperoleh pada produk atc-alg/cts dengan nilai IC 50 sebesar 4079,88 ppm. Analisis stabilitas menunjukkan produk masih dapat disimpan pada temperatur $25{ }^{\circ} \mathrm{C}$. Total antosianin terenkapsulasi terendah ditunjukkan pada produk dengan temperatur penyimpanan $40{ }^{\circ} \mathrm{C}$ selama 16 hari sebesar 9,02 $\mathrm{mg} / \mathrm{L}$. Berdasarkan hasil tersebut dapat disimpulkan bahwa penyalut yang tepat untuk produk enkapsulasi ekstrak antosianin adalah penyalut Ca-alginat/kitosan.
\end{abstract}

Kata Kunci : Enkapsulasi, Ekstrusi, Antosianin, Alginat, Kitosan 


\section{PENDAHULUAN}

Rosela (Hibiscus sabdariffa L.) termasuk dalam famili Malvaceae yang banyak ditemukan di daerah Asia dan Afrika. Kelopak bunga Rosela kaya akan pigmen merah antosianin, seperti delpinidi-3glukosida, delpinidin-3-sambubiosida, sianidin-3-glukosida, dan sianidin-3sambubiosida [1] yang mendapat banyak perhatian karena berpotensi sebagai sumber pewarna merah alami dalam industri makanan, farmasi, dan kosmetik [2]. Antosianin termasuk dalam golongan senyawa flavonoid yang berperan dalam memberikan warna pada bunga, buah, dan sayuran. Selain memiliki kekhasan sebagai sumber pewarna alami, antosianin dari Rosela juga memiliki aktivitas biologis seperti aktivitas antioksidan, menurunkan tekanan darah, dan berpengaruh pada fungsi diuretic, antikanker, dan meningkatkan sistem pencernaan pada manusia [3].

Namun, beberapa penelitian telah melaporkan bahwa antosianin memiliki stabilitas yang sangat rendah dan rentan terdegradasi. Stabilitas antosianin dipengaruhi oleh beberapa faktor seperti $\mathrm{pH}$, temperatur penyimpanan, konsentrasi, cahaya, oksigen, pelarut, copigmentasi, keberadaan enzim, protein dan ion logam [4]. Salah satu alternatif untuk menjaga dan meningkatkan stabilitas antosianin adalah metode enkapsulasi, yaitu metode melapisi atau menjebak senyawa bioaktif di dalam matrik [5]. Metode enkapsulasi telah banyak digunakan untuk mengurangi interaksi senyawa bioaktif dengan faktor lingkungan, seperti temperatur, cahaya, kelembaban, dan oksigen.

Hingga saat ini, topik penelitian enkapsulasi antosianin dari berbagai sumber tanaman juga sangat bervariasi. Mahdavi dkk [6] telah melakukan enkapsulasi ekstrak antosianin dari Barberry (Berberis vulgaris) menggunakan kombinasi penyalut maltodekstrin dan gum arabik dengan rasio core/wall 25\%. Kanokpanont [7] juga telah melakukan enkapsulasi ekstrak antosianin dari buah Mulberi menggunakan penyalut alginat/kitosan sebagai aplikasi suplemen makanan dengan metode spray drying dan external gelation. Selain itu, pengembangan metode dalam enkapsulasi dengan penyalut atau matriks yang berbeda terkait enkapsulasi antosianin dari kelopak bunga Rosela telah banyak dilaporkan, diantaranya penggunaan penyalut maltodekstrin-gum arabik dengan metode spray drying, dan stabilitas antosianin dari Rosela dengan metode double emulsion dan ionic gelation [8, 9].

Penelitian yang telah ada belum menjelaskan produk enkapsulasi ekstrak antosianin dari 
bunga Rosela dengan penyalut alginat dan kitosan, sehingga pada penelitian ini dilakukan enkapsulasi ekstrak antosianin dari bunga Rosela dengan penyalut alginat yang ditaut silang dengan kalsium klorida $\left(\mathrm{CaCl}_{2}\right)$, kitosan yang ditaut silang dengan natrium tripolifosfat (Na-TPP), dan alginat-kitosan yang ditaut silang dengan kalsium klorida $\left(\mathrm{CaCl}_{2}\right)$ menggunakan metode ekstrusi. Kedua penyalut dipilih karena memiliki sifat biodegradable, tidak beracun, dan stabil terhadap termal [7]. Alginat merupakan polimer polisakarida dengan struktur dasar yang terdiri dari unit $(1 \rightarrow 4)-\beta$-D-asam manuronat $(\mathrm{M})$ dan unit $(1 \rightarrow 4)-\alpha$-L-asam guluronat (G). Dalam kondisi $\mathrm{pH}$ asam, natrium alginat cenderung memiliki viskositas yang rendah. Natrium alginat akan membentuk larutan kental seperti suspensi ketika dalam pelarut air dan membentuk gel dengan adanya kation divalent, seperti $\mathrm{Ca}^{2+}$ [10]. Kitosan merupakan biopolimer alam yang bersifat basa lemah dan polikationik yang tidak beracun, serta polisakarida linear yang tersusun atas unit $N$-asetyl-Dglucosamine dan D-glucosamine yang dihubungkan oleh $\beta$-(1-4) [7].

Tujuan dari penelitian ini adalah menentukan penyalut yang tepat dari ketiga variasi penyalut untuk produk enkapsulasi ekstrak antosianin dalam hal nilai efisiensi enkapsulasi dan aktivitas antioksidan, menentukan aktivitas antioksidan produk, serta menentukan stabilitas produk terhadap temperatur $\left(4,25\right.$ dan $\left.40{ }^{\circ} \mathrm{C}\right)$ dan waktu penyimpanan (hari ke-0, 6 dan 16) dari produk yang menunjukkan aktivitas antioksidan terbesar.

\section{METODE PENELITIAN}

Bahan dan Alat

Bahan yang digunakan dalam penelitian adalah kelopak bunga Rosela (Hibiscus sabdariffa L.) kering yang diperoleh dari Mojosongo, Boyolali, Jawa Tengah, Indonesia, Na-alginat, kitosan, natrium tripolifosfat (Na-TPP) dan aquades diperoleh dari toko kimia lokal di Semarang. 2,2Diphenyl-1-picrylhydrazyl (DPPH), etanol $96 \%$, etanol pa, kalsium klorida $\left(\mathrm{CaCl}_{2}\right)$, kalium klorida, natrium klorida dan asam klorida diperoleh dari Sigma-Aldrich (St Louis, MO, USA).

Peralatan yang digunakan dalam penelitian ini meliputi alat-alat kaca untuk analisis, neraca analitik (Ohaus), syringe 23G, hot plate magnetic stirrer (SH-3), rotary vacuum evaporator (IKA@RV 10 Basic), pH meter (Schott Instruments), spektrofotometer UVVis (HITACHI UH5300), FTIR (PerkinElmer Spectrum IR), dan SEM (JEOL JSM-6510). 
Prosedur

1. Preparasi Ekstrak Antosianin

Ekstraksi antosianin dilakukan dengan menggunakan metode maserasi [1]. Sebanyak 100 g serbuk kelopak bunga Rosela dimaserasi dengan $300 \mathrm{~mL}$ etanol $96 \%$ pada temperatur $25{ }^{\circ} \mathrm{C}$ selama 24 jam dalam kondisi gelap (tanpa cahaya). Filtrat hasil maserasi dipekatkan menggunakan rotary vacuum evaporator. Ekstrak hasil evaporasi dilakukan penghilangan air menggunakan vacuum freeze dryer.

2. Enkapsulasi Ekstrak Antosianin

Proses enkapsulasi ekstrak antosianin pada berbagai penyalut menggunakan metode ekstrusi, yang mana dilakukan penetesan larutan enkapsulasi (campuran ekstrak antosianin dan penyalut) melalui syringe secara perlahan pada larutan crosslinker yang sesuai dengan penyalut yang digunakan, sehingga akan terbentuk kapsul atau beads. Dalam penelitian ini, enkapsulan atau penyalut yang digunakan untuk menjerat ekstrak antosianin adalah penyalut alginat dengan crosslinker kalsium klorida $\left(\mathrm{CaCl}_{2}\right)$, kitosan dengan crosslinker natrium tripolifosfat (Na-TPP), dan penyalut alginatkitosan dengan crosslinker kalsium klorida $\left(\mathrm{CaCl}_{2}\right)$. Produk enkapsulasi yaitu antosianinalginat (atc-alg), antosianin-kitosan (atc-cts), dan antosianin alginat/kitosan (atc-alg/cts) [1, $7,10]$.

\section{Uji Efisiensi Enkapsulasi}

Efisiensi enkapsulasi (\%EE) antosianin terenkapsulasi ditentukan melalui penentuan total anthocyanin content (TAC) dan surface anthocyanin content (SAC) dari produk [6]. TAC diperoleh dari $400 \mathrm{mg}$ produk yang dilarutkan dalam $4 \mathrm{~mL}$ aquades. Kemudian, dilakukan penambahan $6 \mathrm{~mL}$ etanol pro analysis dan disaring.

Ekstraksi surface anthocyanin dari $400 \mathrm{mg}$ produk dilakukan dengan cepat menggunakan $10 \mathrm{~mL}$ etanol pro analysis dalam vortex selama 10 detik, diikuti dengan sentrifugasi pada 3000 rpm selama 10 menit. Supernatan jernih disaring melalui membran millipore berukuran $0,45 \mu \mathrm{m}$. Kuantifikasi dilakukan menggunakan metode $\mathrm{pH}_{\text {- }}$ differential oleh AOAC, menggunakan dua sistem buffer yaitu buffer $\mathrm{KCl}$ pH $1(0,025$ $\mathrm{M})$ dan buffer $\mathrm{CH}_{3} \mathrm{COONa} \mathrm{pH} 4,5(0,4 \mathrm{M})$. Kemudian absorbansi setiap larutan diukur pada panjang gelombang 520 dan $700 \mathrm{~nm}$. Absorbansi sampel (A) yang telah dilarutkan ditentukan dengan persamaan 1 [12].

$\mathrm{A}=\left(\mathrm{A}_{520}-\mathrm{A}_{700}\right)_{\mathrm{pH} 1,0}-\left(\mathrm{A}_{520}-\mathrm{A}_{700}\right)_{\mathrm{pH} 4,5}(1)$

Dimana, A520 adalah absorbansi pada panjang gelombang $520 \mathrm{~nm}, \mathrm{~A}_{700}$ adalah absorbansi pada panjang gelombang $700 \mathrm{~nm}$, kedua 
Oktavi, dkk. Akta Kimia Indonesia 5(2), 2020, 86-101

panjang gelombang digunakan untuk mengukur larutan sampel pada kondisi $\mathrm{pH} 1$ dan $\mathrm{pH} 4,5$.

TAC dan SAC sebagai sianidin-3-glukosida pada sampel dihitung menggunakan persamaan 2 [12].

Amount of anthocyanins $\left(\frac{m g}{L}\right)=$ $\frac{A . M W \cdot D F .1000}{\varepsilon . L}(2)$

Dimana, $\varepsilon$ adalah absorptivitas molar sianidin-3-glukosida (26.900 L. $\left.\mathrm{mol}^{-1} \mathrm{~cm}^{-1}\right)$, L adalah lebar cuvet $(1 \mathrm{~cm})$, MW adalah berat molekul sianidin-3-glukosida (449,2 g/mol), dan DF adalah faktor pengenceran.

Efisiensi enkapsulasi (\%EE) dihitung sesuai dengan persamaan 3 melalui hasil dari total anthocyanin content (TAC) dan surface anthocyanin content (SAC) [12].

$\% \mathrm{EE}=\frac{T A C-S A C}{T A C} \times 100 \%(3)$

\section{Karakterisasi Produk}

\subsection{Fourier Transform Infrared Spectroscopy}

Karakterisasi FTIR bertujuan untuk mengidentifikasi keberadaan gugus fungsi dari suatu sampel, sehingga dapat diperkirakan interaksi atau ikatan yang terjadi dalam sampel tersebut. Produk enkapsulasi, ekstrak antosianin, Na-alginat dan kitosan dikarakterisasi dengan FTIR dengan range bilangan gelombang $400 \mathrm{~cm}^{-1}-4000 \mathrm{~cm}^{-1}$.

\subsection{Scanning Electron Microscope}

Karakterisasi terhadap morfologi permukaan dari produk enkapsulasi dilakukan menggunakan instrumen SEM. Masingmasing produk dilapisi dengan platinum, kemudian diukur dengan perbesaran 50x dan 3000x.

\section{Uji Aktivitas Antioksidan}

Uji aktivitas antioksidan dilakukan pada semua produk enkapsulasi menggunakan metode DPPH. Produk enkapsulasi ekstrak antosianin dibuat variasi konsentrasi 500, 1000, 2000, 4000, dan 8000 ppm dalam metanol. Kemudian masing-masing konsentrasi dipipet sebanyak $2 \mathrm{~mL}$ dan ditambahkan $2 \mathrm{~mL}$ larutan DPPH 40 ppm dalam metanol. Campuran dihomogenkan dan diinkubasi selama 30 menit tanpa terkena cahaya [13]. Sampel yang telah diinkubasi diukur menggunakan spektrofotometer UVVis pada panjang gelombang $516 \mathrm{~nm}$. Kemampuan untuk meredam radikal DPPH (inhibisi) dihitung menggunakan persamaan 4 [13]. Dimana, $A_{o}$ adalah absorbansi larutan DPPH, As adalah absorbansi larutan sampel.

\%inhibisi $=\frac{A o-A s}{A o} \times 100 \%$ (4)

6. Uji Stabilitas Produk Enkapsulasi 
Oktavi, dkk. Akta Kimia Indonesia 5(2), 2020, 86-101

Sebanyak $100 \mathrm{mg}$ sampel diletakkan pada botol vial dan disimpan pada temperatur 4, 25 , dan $40^{\circ} \mathrm{C}$, tanpa paparan cahaya selama 16 hari. Pengukuran total antosianin dilakukan pada hari ke-0, 6 dan 16. Stabilitas produk diamati terhadap temperatur dan waktu penyimpanan dengan mengukur kandungan total antosianin sebagai sianidin3-glukosida menggunakan metode $\mathrm{pH}$ differential [14].

\section{HASIL DAN PEMBAHASAN}

\section{Ekstraksi Antosianin}

Hasil ekstrak antosianin yang diperoleh dari kelopak bunga Rosela berwarna merah tua dengan rendemen ekstrak sebesar 7,984\%.
2. Produk Enkapsulasi Ekstrak Antosianin

Produk enkapsulasi ekstrak antosianin ditunjukkan pada Gambar 1. Produk atc-alg berupa padatan yang berbentuk bulat, keras dan seragam, serta memiliki warna merah muda. Produk atc-cts berupa padatan yang berbentuk pipih bulat, mudah rusak dan memiliki warna coklat. Kemudian untuk produk atc-alg/cts berupa padatan yang berbentuk bulat, keras dan memiliki warna merah tua. Perbedaan warna produk dikarenakan adanya perbedaan interaksi yang berakibat pada perubahan transisi elektron.

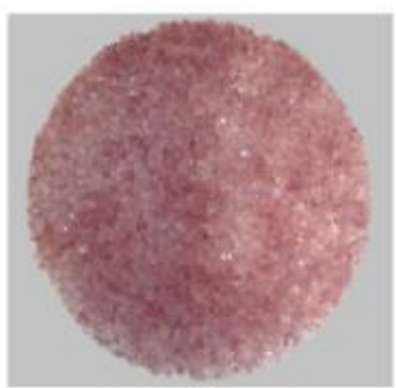

(a)

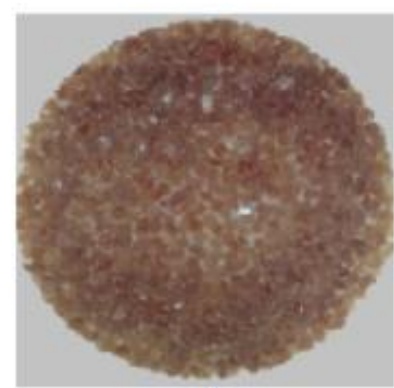

(b)

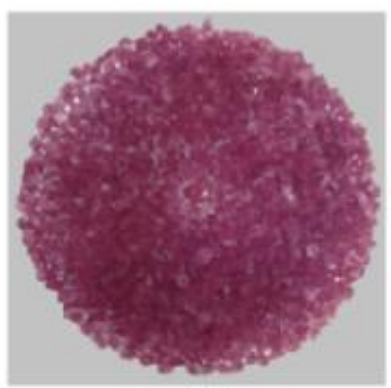

(c)

Gambar 1. Produk enkapsulasi menggunakan penyalut: (a) atc-alg; (b) atc-cts; dan (c) atc-alg/cts

Tabel 1. Nilai efisiensi enkapsulasi produk enkapsulasi

\begin{tabular}{cc}
\hline Produk Enkapsulasi & Nilai EE (\%) \\
\hline Atc-alg & 94,44 \\
Atc-cts & 93 \\
Atc-alg/cts & 98,28 \\
\hline
\end{tabular}




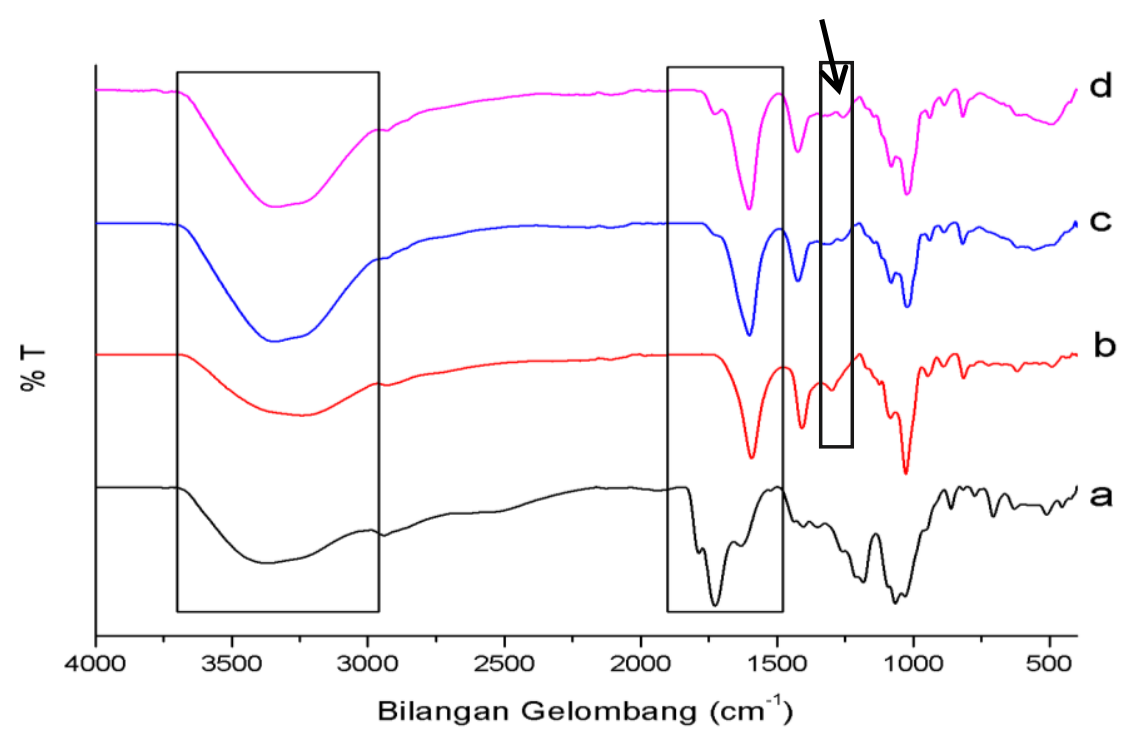

Gambar 2. Spektrum FTIR: (a) ekstrak antosianin; (b) Na-alginat; (c) Ca-alginat; dan (d) produk atc-alg

Produk atc-cts mudah rusak dikarenakan larutan Na-TPP yang digunakan sebagai crosslinker dalam kondisi pH 2,6. Jumlah ion amonium dari kitosan terprotonasi cukup pada $\mathrm{pH}$ 6,3. Pada kondisi sangat asam, penambahan proton berlebih menyebabkan terbentuknya polikation $\left(\mathrm{NH}_{4}^{+}\right)$yang lebih banyak, sehingga kitosan lebih larut yang mengakibatkan interaksi hidrogen antara rantai polimer menjadi terbatas [15]. Selain itu, dimungkinkan ion tripolifosfat berinteraksi terlebih dahulu dengan proton dari larutan asam, sehingga mengurangi interaksi elektostatik antara polikation kitosan dengan polianion tripolifosfat yang berakibat pada bentuk beads yang lebih lunak dan rentan rusak [16].

3. Uji Efisiensi Enkapsulasi

Penentuan nilai efisiensi enkapsulasi dari masing-masing produk dapat dilihat pada Tabel 1 yang menunjukkan nilai efisiensi enkapsulasi terbesar adalah produk atcalg/cts sebesar 98,28\%. Hal tersebut menunjukkan bahwa adanya penambahan kitosan dalam enkapsulasi dengan penyalut alginat dapat meningkatkan stabilitas dari alginat ditunjukkan dengan meningkatnya nilai efisiensi enkapsulasi. Kedua polimer yaitu alginat dan kitosan akan membentuk kompleks polielektrolit melalui interaksi 
Oktavi, dkk. Akta Kimia Indonesia 5(2), 2020, 86-101

ionik antara gugus karboksilat $\left(\mathrm{COO}^{-}\right)$yang tersisa dari alginat dengan ion amonium $\left(\mathrm{NH}_{4}{ }^{+}\right)$dari kitosan [17]. Kompleksasi alginat dengan kitosan mengurangi porositas gel alginat dan adanya kitosan dapat melapisi beads alginat, sehingga laju difusi dari zat dapat dikendalikan [15]. Selain itu, adanya kitosan meningkatkan interaksi hidrogen, sehingga dimungkinkan lebih banyak antosianin yang terjerap di dalam kompleksasi alginat-kitosan.

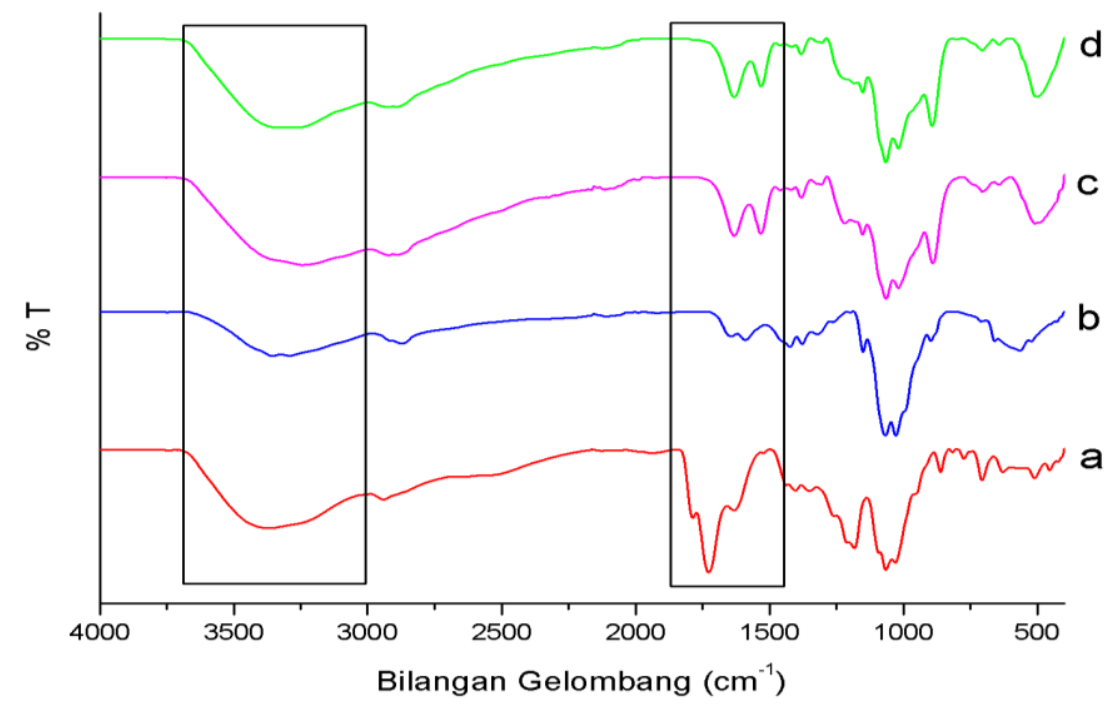

Gambar 3. Spektrum FTIR: (a) ekstrak antosianin; (b) Kitosan; (c) Kitosan-TPP; dan (d) produk atc-cts

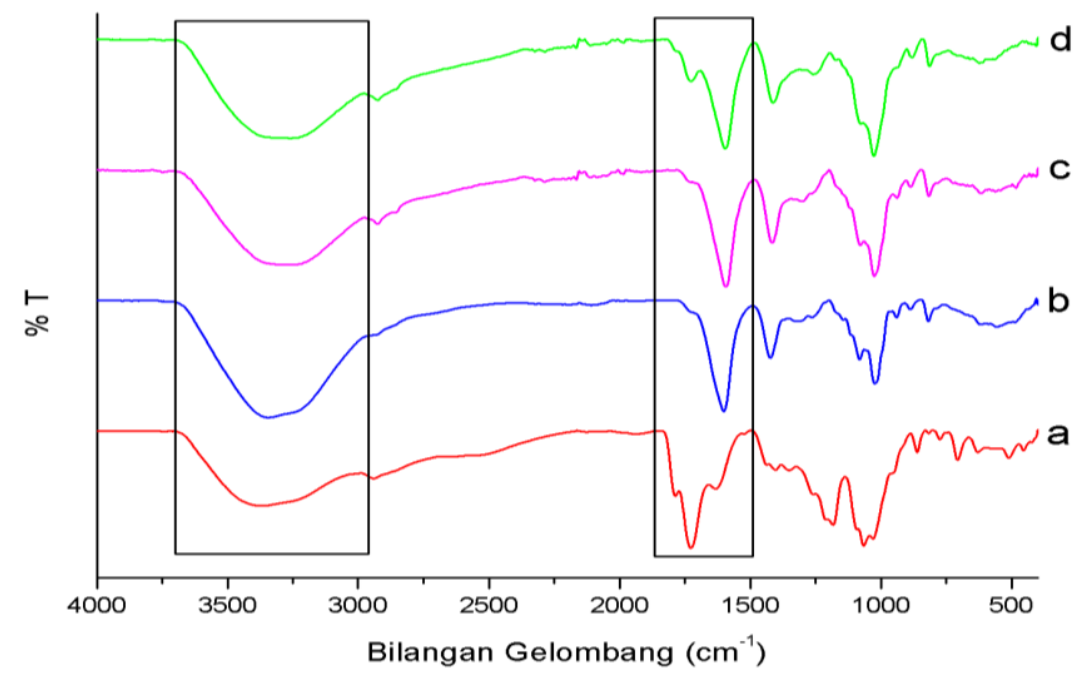

Gambar 4. Spektrum FTIR: (a) ekstrak antosianin; (b) Ca-alginat; (c) alginat/kitosan; dan (d) produk atc-alg/cts 


\section{Karakterisasi Produk}

\subsection{Fourier Transform Infrared Spectroscopy}

Spektrum FTIR dari ekstrak antosianin, natrium alginat, kalsium alginat, dan produk enkapsulasi atc-alg ditunjukkan pada Gambar 2. Spektra FTIR dari ekstrak antosianin yang ditampilkan pada Gambar 2a, 3a, dan 4a menunjukkan puncak khas yang hanya dimiliki oleh ekstrak antosianin yaitu pada bilangan gelombang $2940 \mathrm{~cm}^{-1}$ (ikatan $-\mathrm{CH}$ ulur), $1787 \mathrm{~cm}^{-1}$ dan $1727 \mathrm{~cm}^{-1}$ (ikatan $\mathrm{C}=\mathrm{O}$ ulur), $1632 \mathrm{~cm}^{-1}$ (ikatan $\mathrm{C}=\mathrm{C}$ ), dan puncak pada bilangan gelombang $3372 \mathrm{~cm}^{-1}$ menunjukkan adanya vibrasi dari gugus hidroksil (O-H) dan karboksil (C-H) [18]. Selain itu, terdapat serapan pada bilangan gelombang $1065 \mathrm{~cm}^{-1}$ yaitu vibrasi dari cincin aromatik dan gugus $=\mathrm{C}-\mathrm{O}-\mathrm{C}$ dari flavonoid [19].

Spektra Na-alginat (Gambar 2b) menunjukkan pita serapan yang khas pada bilangan gelombang $1592 \mathrm{~cm}^{-1}$ (asimetris $\mathrm{COO}^{-}$ulur) dan $1408 \mathrm{~cm}^{-1}$ (simetris $\mathrm{COO}^{-}$ ulur dan ikatan O-H tekuk), pita serapan ini mengalami pergeseran bilangan gelombang menjadi $1600 \mathrm{~cm}^{-1}$ (asimetris $\mathrm{COO}^{-}$ulur) dan $1422 \mathrm{~cm}^{-1}$ (simetris $\mathrm{COO}^{-}$ulur dan ikatan O$\mathrm{H}$ tekuk) yang diperkirakan karena adanya interaksi yang kuat antara anion karboksilat dan kation kalsium. Spektra dari Na-alginat
(Gambar 2b) dan Ca-alginat (Gambar 2c) menunjukkan adanya pergeseran bilangan gelombang dari $3240 \mathrm{~cm}^{-1} \mathrm{ke} 3343 \mathrm{~cm}^{-1}$ untuk ikatan $\mathrm{O}-\mathrm{H}$, selain itu pada daerah hidroksil ini puncak spektra b lebih lebar dibandingkan spektra c, dimungkinkan gugus hidroksil dari alginat berinteraksi dengan $\mathrm{Ca}^{2+}$. Spektra dari produk atc-alg (Gambar 2d) menunjukkan adanya pita serapan baru yang mulanya tidak dimiliki oleh spektra $\mathrm{Na}$ alginat dan Ca-alginat yaitu pada bilangan gelombang $1727 \mathrm{~cm}^{-1}$ merupakan pita serapan ikatan $\mathrm{C}=\mathrm{O}$ yang dimiliki oleh spektra ekstrak antosianin. Selain itu, muncul pita serapan pada bilangan gelombang 1240 $\mathrm{cm}^{-1}$ yang menunjukkan adanya vibrasi gugus C-O-C dan jika dibandingkan serapan simetris $\mathrm{COO}^{-}$dan asimetris $\mathrm{COO}^{-}$dari $\mathrm{Ca}-$ alginat dengan produk atc-alg mengalami pergeseran dari $1600 \mathrm{~cm}^{-1}$ dan $1422 \mathrm{~cm}^{-1}$ menjadi $1601 \mathrm{~cm}^{-1}$ dan $1423 \mathrm{~cm}^{-1}$, kedua perubahan mengindikasikan adanya interaksi hidrogen antara senyawa dalam ekstrak dengan alginat seperti penelitian yang dilaporkan oleh Gorbunova [20].

Spektra kitosan (Gambar 3b) menunjukkan pita penyerapan yang khas pada bilangan gelombang $2872 \mathrm{~cm}^{-1}$ (ikatan $\mathrm{N}-\mathrm{H}$ ulur), $1620 \mathrm{~cm}^{-1}$ (ikatan $\left.\mathrm{C}=\mathrm{O}\right), 1589 \mathrm{~cm}^{-1}$ (ikatan $\mathrm{N}-\mathrm{H}$ tekuk) dan $1067 \mathrm{~cm}^{-1}$ (ikatan $\mathrm{C}-\mathrm{H}$ ), pergeseran bilangan gelombang terjadi 
setelah penambahan tripolifosfat yang ditunjukkan pada Gambar 3c. Kemudian, spektra cts-TPP (Gambar 3c) menunjukkan adanya serapan baru di daerah bilangan gelombang $1248 \mathrm{~cm}^{-1}$ yaitu serapan dari ikatan $\mathrm{P}=\mathrm{O}$ dari tripolifosfat [21]. Spektra dari produk atc-cts (Gambar 3d) memiliki puncak yang hampir sama dengan puncakpuncak pada kitosan. Puncak pada bilangan gelombang $1631 \mathrm{~cm}^{-1}$ menunjukkan semakin luas dimungkinkan ikatan $\mathrm{C}=\mathrm{C}$ meningkat, karena ikatan ini juga dimiliki oleh ekstrak antosianin, artinya terdapat ekstrak antosianin yang terenkapsulasi. Selain itu, terjadi pergeseran bilangan gelombang dari $1589,97 \mathrm{~cm}^{-1}$ menjadi $1532,47 \mathrm{~cm}^{-1}$ yang menunjukkan adanya protonisasi $\mathrm{NH}_{4}{ }^{+}$dari kitosan. Protonasi ini akan berinteraksi dengan ion tripolifosfat [16]. Spektra dari produk atc-cts menunjukkan seamakin luasnya puncak pada bilangan gelombang $3240 \mathrm{~cm}^{-1}$ (gugus hidroksil $\mathrm{OH}$ dan gugus amina $\mathrm{N}-\mathrm{H}$ ) artinya kemungkinan terjadi peningkatan interaksi hidrogen dengan adanya ekstrak antosianin.

Gambar 4(a-d) menunjukkan spektra FTIR dari ekstrak antosianin, Ca-alginat, cts-alg (tanpa ekstrak antosianin) dan produk atcalg/cts. Spektra Ca-alginat (Gambar 4b) dan cts-alg (Gambar 4c) menunjukkan adanya pergeseran bilangan gelombang dari $3343 \mathrm{~cm}^{-}$ ${ }^{1}$ ke $3258 \mathrm{~cm}^{-1}$ untuk ikatan hidroksil (O-H), hal ini diakibatkan adanya penambahan kitosan. Selain itu, puncak pada bilangan gelombang $1600 \mathrm{~cm}^{-1}$ dan $1422 \mathrm{~cm}^{-1}$ menunjukkan adanya gugus karboksil (simetrik $\mathrm{COO}^{-}$dan asimetrik $\mathrm{COO}^{-}$) dari alginat. Puncak tersebut mengalami sedikit pergeseran dari $1600 \mathrm{~cm}^{-1}$ ke $1593 \mathrm{~cm}^{-1}$ dan $1422 \mathrm{~cm}^{-1}$ ke $1415 \mathrm{~cm}^{-1}$ setelah kompleksasi dengan kitosan. Adanya puncak $1593 \mathrm{~cm}^{-1}$ juga dapat diinterpretasikan keberadaan gugus amina yang terprotonasi yang diperoleh dari N-deasetilasi parsial kitin. Perubahan gugus amino, gugus karboksil, dan ikatan amida dapat dikaitkan dengan interaksi ionik antara gugus karbonil alginat dan gugus amino kitosan [22]. Spektra dari produk atc-alg/cts (Gambar 4d) memiliki puncak serapan baru yang mulanya tidak dimiliki oleh spektra cts-alg yaitu pada bilangan gelombang $1727 \mathrm{~cm}^{-1}$ merupakan pita serapan ikatan $\mathrm{C}=\mathrm{O}$ yang dimiliki oleh spektra ekstrak antosianin.

Tabel 2. Nilai I $\mathrm{C}_{50}$ produk enkapsulasi ekstrak antosianin

\begin{tabular}{cc}
\hline Produk & $\mathrm{IC}_{50}(\mathrm{ppm})$ \\
\hline Atc-alg & 8359,362 \\
Atc-cts & 7535,745 \\
Atc-alg/cts & 4079,884 \\
\hline
\end{tabular}




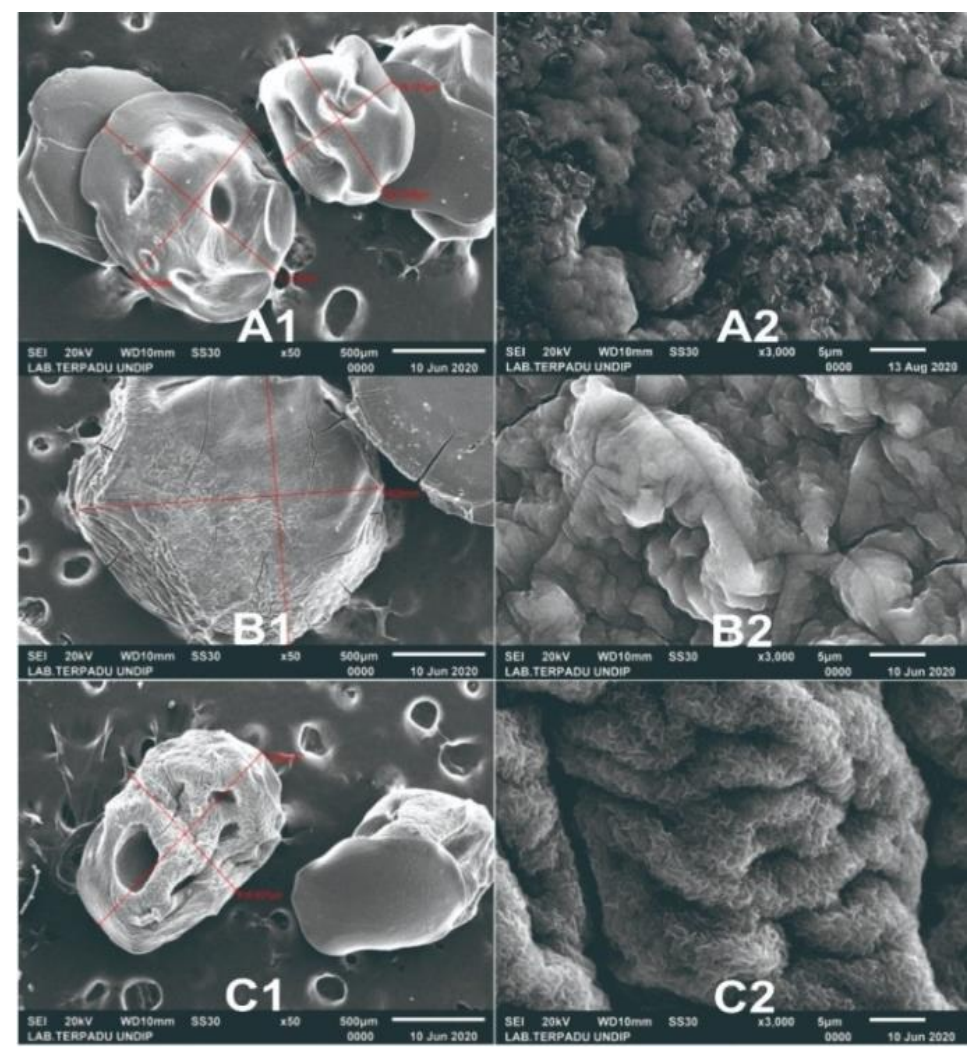

Gambar 5. Hasil SEM enkapsulasi (A1) atc-alg perbesaran 50x, (A2) atc-alg perbesaran 3000x; (B1) atc-cts perbesaran 50x, (B2) atc-cts perbesaran 3000x; (C1) atc-alg/cts perbesaran 50x, dan (C2) atcalg/cts perbesaran $3000 x$

\subsection{Scanning Electron Microscope}

Hasil SEM dari produk enkapsulasi pada perbesaran 50x dan 3000x ditunjukkan pada Gambar 5. Berdasarkan hasil SEM yang ditunjukkan pada Gambar 5 dapat dilihat bahwa setiap produk memiliki bentuk yang berbeda dan beragam, yang mana morfologi produk atc-alg (Gambar 5A1) menunjukkan bentuk yang bulat-lonjong dan memiliki permukaan yang tidak beraturan, serta terdapat sedikit retakan pada permukaan produk. Morfologi dari produk atc-cts (Gambar 5B1) menunjukkan bentuk yang bulat dan memiliki permukaan yang banyak retakan, hal tersebut menyebabkan adanya transfer oksigen yang memungkinkan terjadinya degradasi karena interaksi dengan senyawa aktif [23]. Sedangkan, morfologi produk atc-alg/cts menunjukkan bentuk yang bulat-lonjong, memiliki permukaan yang tidak beraturan dan sedikit lebih kasar (Gambar 5C1).

Jika diamati melalui perbesaran 3000x (Gambar 5A2, 5B2, dan 5C2) dapat dilihat antara produk atc-alg dan atc-cts dengan produk atc-alg/cts memiliki morfologi yang 
berbeda, yang mana pada produk atc-alg/cts memiliki morfologi yang lebih berkerut dan rapat, hal ini menunjukkan bahwa adanya penambahan kitosan dapat merapatkan permukaan beads sehingga mencegah terjadinya degradasi seperti yang terjadi pada enkapsulasi alginat dan kitosan sendiri. Morfologi produk yang diinginkan adalah morfologi yang lebih rapat, berkerut dan tanpa retakan karena memungkinkan lebih sedikit senyawa atau ekstrak yang terdifusi dan terdegradasi.

\section{Uji Aktivitas Antioksidan}

Penentuan nilai $\mathrm{IC}_{50}$ dari masing-masing produk dapat dilihat pada Tabel 2. Dari hasil tersebut menerangkan bahwa aktivitas antioksidan dari produk enkapsulasi sangat lemah ditunjukkan dengan konsentrasi $\mathrm{IC}_{50}$ yang cukup besar. Hal ini berhubungan dengan morfologi yang dihasilkan, yang mana adanya beberapa retakan dari produk dapat memungkinkan antosianin terdifusi, sehingga jumlah ekstrak antosianin terenkapsulasi berkurang. Namun, jika ketiga produk dibandingkan, produk atc-alg/cts memiliki aktivtas antioksidan paling tinggi dibandingkan produk lain, ditunjukkan dengan nilai $\mathrm{IC}_{50}$ yang lebih kecil yaitu sebesar 4079,88 ppm. Perbedaan nilai IC $_{50}$ dikarenakan perbedaan jumlah ekstrak antosianin yang ada dalam produk, artinya semakin banyak ekstrak maka semakin tinggi aktivitas antioksidannya [23].

\section{Uji Stabilitas Antosianin}

Kandungan total antosianin yang terenkapsulasi mula mula sebesar 16,36 mg/L. Kandungan total antosianin terenkapsulasi yang disimpan selama 16 hari pada temperatur $4{ }^{\circ} \mathrm{C}$ sebesar $14,70 \mathrm{mg} / \mathrm{L} ; 25$ ${ }^{\circ} \mathrm{C}$ sebesar $14,03 \mathrm{mg} / \mathrm{L}$; dan $40{ }^{\circ} \mathrm{C}$ sebesar 9,02 mg/L. Ketiga temperatur umum digunakan untuk proses penyimpanan produk yaitu temperatur refrigator, ruang dan luar ruang. Penurunan kandungan total antosianin terbesar ditunjukkan pada produk yang disimpan pada temperatur $40{ }^{\circ} \mathrm{C}$ selama 16 hari yaitu sebesar 9,02 mg/L. Waktu penyimpanan selama 16 hari didasari oleh hasil penelitian Suzery [24] yang mengamati stabilitas produk enkapsulasi phycocyanin selama 3 hari, yang mana hasilnya menunjukkan degradasi senyawa yang sangat kecil, sehingga pada penelitian ini dicoba waktu penyimpanan yang lebih lama sesuai metode yang dilakukan oleh Mehran [18].

Perubahan kandungan total antosianin selama penyimpanan dikarenakan adanya degradasi struktur dari antosianin. Struktur antosianin akan berubah menjadi bentuk aglikon yang dikenal dengan antosianidin. Bentuk aglikon lebih tidak stabil yang menyebabkan terjadinya pembentukan cincin $\mathrm{C}$ pada 
Oktavi, dkk. Akta Kimia Indonesia 5(2), 2020, 86-101

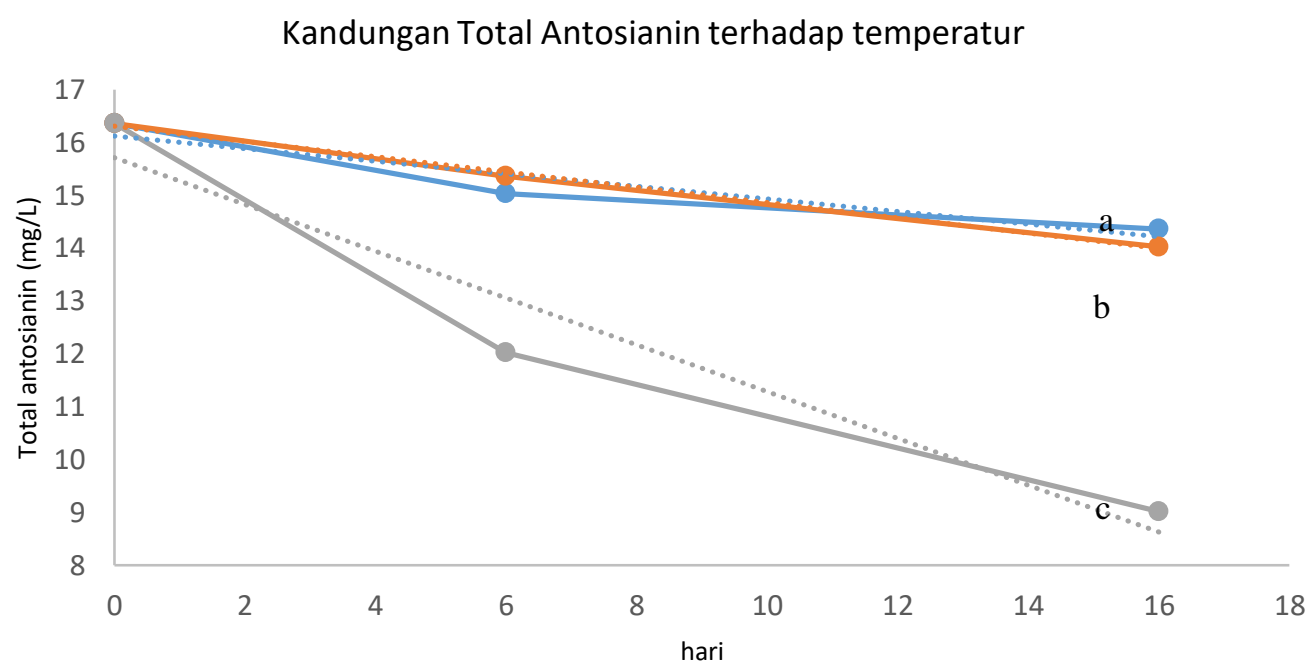

Gambar 6. Kandungan Total Antosianin terenkapsulasi terhadap temperatur: (a) $4{ }^{\circ} \mathrm{C}$; (b) $25^{\circ} \mathrm{C}$; dan (c) $40^{\circ} \mathrm{C}$

struktur antosianidin sehingga terjadi perubahan warna [18]. Grafik kandungan total antosianin terenkapsulasi terhadap temperatur ditampilkan pada Gambar 6.

\section{KESIMPULAN}

Produk enkapsulasi ekstrak antosianin memberikan warna yang beragam dengan nilai efisiensi enkapsulasi terbesar ditunjukkan oleh produk atc-alg/cts yaitu sebesar 98,28\%. Analisis menggunakan FTIR menunjukkan adanya interaksi ionik/elektrostatik dan ikatan hidrogen. Analisis menggunakan SEM menunjukkan produk enkapsulasi atc-alg/cts memiliki morfologi yang lebih berkerut dan rapat dibandingkan dengan produk atc-alg dan atc- cts. Aktivitas antioksidan terbesar ditunjukkan oleh produk atc-alg/cts ditandai dengan nilai $\mathrm{IC}_{50}$ terendah. Penyimpanan antosianin pada temperatur $40^{\circ} \mathrm{C}$ yang disimpan selama 16 hari menyebabkan penurunan total antosianin yang sangat besar. Berdasarkan hasil tersebut dapat disimpulkan bahwa penyalut yang tepat untuk produk enkapsulasi ekstrak antosianin adalah penyalut Ca-alginat/kitosan.

\section{Daftar Pustaka}

[1] M. Suzery, S. Lestari, and B. Cahyono, "Penentuan Total Antosianin Dari Kelopak Bunga Rosela (Hibiscus Sabdariffa L) Dengan Metode Maserasi Dan Sokshletasi,” J. Sains Dan Mat., vol. 18, no. 1, pp. 1-6, 2010. 
Oktavi, dkk. Akta Kimia Indonesia 5(2), 2020, 86-101

[2] K. Duangmal, B. Saicheua, and S. Sueeprasan, "Roselle anthocyanins as a natural food colorant and improvement of its colour stability," Proceedings of the AIC, 2004, pp. 155-158.

[3] S. N. Nichenametla, T. G. Taruscio, D. L. Barney, and J. H. Exon, "A review of the effects and mechanisms of polyphenolics in cancer," Crit. Rev. Food Sci. Nutr., vol. 46, no. 2, pp. 161-183, 2006.

[4] A. Patras, N. P. Brunton, C. O’Donnell, and B. K. Tiwari, "Effect of thermal processing on anthocyanin stability in foods; mechanisms and kinetics of degradation," Trends Food Sci. Technol., vol. 21, no. 1, pp. 3-11, 2010.

[5] M. K. Rai, P. Asthana, S. K. Singh, V. S. Jaiswal, and U. Jaiswal, "The encapsulation technology in fruit plants-A review," Biotechnol. Adv., vol. 27, no. 6, pp. 671-679, 2009.

[6] S. Akhavan Mahdavi, S. M. Jafari, E. Assadpoor, and D. Dehnad, "Microencapsulation optimization of natural anthocyanins with maltodextrin, gum Arabic and gelatin,” Int. J. Biol. Macromol., vol. 85, pp. 379-385, 2016.

[7] S. Kanokpanont, R. Yamdech, and P. Aramwit, "Stability enhancement of mulberry-extracted anthocyanin using alginate/chitosan microencapsulation for food supplement application," Artif. Cells,
Nanomedicine Biotechnol., vol. 46, no. 4, pp. 773-782, 2018.

[8] D. Archaina, G. Leiva, D. Salvatori, and C. Schebor, "Physical and functional properties of spray-dried powders from blackcurrant juice and extracts obtained from the waste of juice processing," Food Sci. Technol. Int., vol. 24, no. 1, pp. 78-86, 2018. [9] S. C. S. R. de Moura, C. L. Berling, S. P. M. Germer, I. D. Alvim, and M. D. Hubinger, "Encapsulating anthocyanins from Hibiscus sabdariffa L. calyces by ionic gelation: Pigment stability during storage of microparticles," Food Chem., vol. 241, no. August 2017, pp. 317-327, 2018.

[10] K. Y. Lee and D. J. Mooney, "Alginate: Properties and biomedical applications," Prog. Polym. Sci., vol. 37, no. 1, pp. 106-126, 2012.

[11] W. Wang, J. Jung, and Y. Zhao, "Chitosan-cellulose nanocrystal microencapsulation to improve encapsulation efficiency and stability of entrapped fruit anthocyanins," Carbohydr. Polym., vol. 157, pp. 1246-1253, 2017.

[12] M. Mónica Giusti and R. E. Wrolstad, "Characterization and Measurement of Anthocyanins by UV-visible Spectroscopy," Handb. Food Anal. Chem., vol. 2-2, pp. 1931, 2005.

[13] P. Molyneux, "The Use of the Stable Free Radical Diphenylpicryl-hydrazyl 
(DPPH) for Estimating Antioxidant Activity," Songklanakarin J. Sci. Technol., vol. 26, no. December 2003, pp. 211-219, 2004.

[14] M. Suzery et al., "The improvement of phycocyanin stability extracted from Spirulina sp using extrusion encapsulation technique," AIP Conf. Proc., vol. 1699, pp. 0-4, 2015.

[15] S. Afzal, M. Maswal, and A. A. Dar, "Rheological behavior of $\mathrm{pH}$ responsive composite hydrogels of chitosan and alginate: characterization and its use in encapsulation of citral," Colloids Surfaces B Biointerfaces, vol. 169, pp. 99-106, 2018.

[16] U. Laila, R. Rochmadi, and S. Pudjiraharti, "Microencapsulation of PurpleFleshed Sweet Potato Anthocyanins with Chitosan-Sodium Tripolyphosphate by Using Emulsification-Crosslinking Technique," $J$. Math. Fundam. Sci., vol. 51, no. 1, pp. 2946, 2019.

[17] L. Segale, L. Giovannelli, P. Mannina, and F. Pattarino, "Calcium alginate and calcium alginate-chitosan beads containing celecoxib solubilized in a self-emulsifying phase," Scientifica (Cairo)., vol. 2016, 2016.

[18] M. Mehran, S. Masoum, and M. Memarzadeh, "Improvement of thermal stability and antioxidant activity of anthocyanins of Echium amoenum petal using maltodextrin/modified starch combination as wall material," Int. J. Biol. Macromol., vol. 148, pp. 768-776, 2020.

[19] L. I. L. Favaro et al., "Physicochemical characterization of a crude anthocyanin extract from the fruits of Jussara (Euterpe edulis Martius): potential for food and pharmaceutical applications," J. Braz. Chem. Soc., vol. 29, no. 10, pp. 2072-2088, 2018.

[20] N. Gorbunova, A. Bannikova, A. Evteev, I. Evdokimov, and S. Kasapis, "Alginate-based encapsulation of extracts from beta Vulgaris cv. beet greens: Stability and controlled release under simulated gastrointestinal conditions," $L W T$, vol. 93, pp. 442-449, 2018.

[21] B. Cahyono, M. Suzery, H. Hadiyanto, and S. B. Pratiwi, "Encapsulation Rutin with Chitosan-NATPP Using Coaservation Method," Reaktor, vol. 17, no. 4, pp. 215220.

[22] B. Sarmento, D. Ferreira, F. Veiga, and A. Ribeiro, "Characterization of insulinloaded alginate nanoparticles produced by ionotropic pre-gelation through DSC and FTIR studies," Carbohydr. Polym., vol. 66, no. 1, pp. 1-7, 2006.

[23] A. G. da Silva Carvalho, M. T. da Costa Machado, H. D. de F. Q. Barros, C. B. B. Cazarin, M. R. M. Junior, and M. D. Hubinger, "Anthocyanins from jussara (Euterpe edulis Martius) extract carried by calcium alginate beads pre-prepared using 
Oktavi, dkk. Akta Kimia Indonesia 5(2), 2020, 86-101

ionic gelation," Powder Technol., vol. 345, pp. 283-291, 2019.

[24] M. Suzery, D. Majid, D. Setyawan, H.

Sutanto, and others, "Improvement of stability and antioxidant activities by using phycocyanin-chitosan encapsulation technique," in IOP Conference Series: Earth and Environmental Science, 2017, vol. 55, no. 1, p. 12052. 